\title{
ANALYSIS OF THE EFFECT OF EDUCATION FUNDS, HEALTH FUNDS, AND LABOR FUNDS ON REGIONAL INCOME IN SOUTH TANGERANG CITY PERIOD 2013 - 2018
}

\author{
By: \\ Firdaus Budhy Saputro \\ Economic Education Study Program \\ Faculty of Education and Social Sciences \\ Indraprasta University PGRI
}

Email:

ovier2008@gmail.com

\begin{abstract}
This study aims to analyze the effect of education funds, health funds, and labor funds on regional income partially and simultaneously. The analysis uses panel data with multiple regression models or multiple regression. The data used in this study are secondary data obtained in ready-made form from www.djpk.depkeu.go.id and www.bps.go.id. The data obtained are data in an annual form for each variable. The research period is data from 2013 to 2018. The results of this study indicate that the health fund variable has a partial effect on gross domestic product. While the variable education funding and employment absorption do not have a partial effect on gross domestic product. The results of simultaneous panel data regression, the results of the $\mathrm{F}$ test show that the three independent variables namely education funds, health funds and absorption of labor funds simultaneously influence the gross regional domestic product (GRDP).
\end{abstract}

Keywords: education funds, gross regional domestic products, health funds, labor funds 


\section{A. INTRODUCTION}

One measure of economic growth is national income. A country's national income can show how much overall economic activity. The concept of national income is the measure most often used as an indicator of economic growth but is not the only indicator of economic growth. Economic growth is an increase in the total output of an economy. If output grows faster than population, output per capita increases and living standards rise (Case dan Fair, 2015:27).

To increase the gross regional domestic product (GRDP) of an area needs to know what factors can influence it. One factor is education, in economic development education is seen as an investment in human capital. With this investment, it is expected to obtain benefits, including income derived from participation in the labor market. Only education can find ways and methods of economic development and only with the results of education, people will be able to care for their economy. On the other hand, people also argue that economic growth can be the cause of educational growth because economic growth requires educated people. (Abdullah, 2016: 12)

Other factors that can influence gross regional domestic product (GRDP) are the level of public health, high economic growth or increased income can have no meaning if there is no access to basic needs, if those basic needs are health services, educational services, government administration services, high economic growth or increased income can have no meaning if people do not have access to health services.

Human resource development can be done by improving the quality of human capital. Human capital can refer to education, but it can also be used to explain other types of human investment, investment that leads to a healthy population, namely health. (Mankiw, 2012: 15). Education and health are fundamental development goals in an area. Health is the core of well-being, and education is essential to achieving a decent life. Education has an important role in shaping the ability of a developing country to absorb modern technology and to develop the capacity to create sustainable growth and development (Todaro, 2012: 20).

Allocation of government budgets for education and health is the most important part of budget policy, this policy is related to the government's role as a provider of public goods. The impact of externalities from budget allocation policies for these two fields is certainly expected to affect increasing the ability of human capital to drive economic growth. Education expenditure budget consists of expenses for implementing lessons, for school administration, maintenance of school facilities and infrastructure, school staff welfare, administration, educational technical guidance and data collection (Sudjana, 2017: 289).

Government expenditure has a very strategic position in increasing the rate of economic growth. The government through policy instruments can save the situation when the economy experiences sluggishness due to the economic recession. A country must have a government that functions as a buffer for economic and political turmoil both from within the country and abroad. Shock absorbers in the sense of being able to stabilize the situation become more 
conducive through various policies. The government is a very important actor in a country's economy. An economic activity will be optimal if there are government activities in it. The government can be a perpetrator of economic activities that spur production and consumption. Private parties usually allocate their resources through market mechanisms, if the market system is really efficient in allocating resources, then the role of government is limited, one of which is when there is a failure in the private market. (Samuelson and Nordhaus, 2012: 23).

There are four factors as sources of economic growth. These factors are (1) human resources, (2) natural resources, (3) capital formation, and (4) technology. (Samuelson and Nordhaus, 2012: 22). Government expenditure plays a role in capital formation through government expenditure in various fields such as facilities and infrastructure. The formation of capital in the field of facilities and infrastructure generally becomes social overhead capital (SOC) which is very important in economic growth. This SOC is very important because the private sector will not want to provide various public facilities, but without this public facility the private sector is not interested in investing. Economic growth and income growth will be driven up by the availability of various public facilities.

Another factor that is capable of influencing gross regional domestic product is labor. In Law 13 of 2003, every person who can do work that produces goods or services, both to meet their own needs and for the community is called labor (Agusmidah, 2012: 6).

\section{B. LITERATURE REVIEW}

\section{Government Fund Theory}

Development Model About Development of Government Expenditures. This model was developed by Rostow and Musgrave which links the development of government spending with the stages of economic development which are distinguished between the initial, intermediate, and advanced stages. In the initial stages of economic development, the percentage of government investment to total large investment, because at this stage the government must provide infrastructure, such as education, health, transportation infrastructure, and so on. In the intermediate stage of economic development, government investment is still needed to increase economic growth so that it can take off, but at this stage, the role of private investment has been increasingly enlarged. At a further economic level, Rostow said in Mangkoesoebroto (2012: 170), that economic development of government activities shifted from providing infrastructure to expenditures for social activities such as old age welfare programs, public health service programs, and so on.

Wagner's theory of the development of government spending is called the Wagner law of increased government activity. This theory suggests the development of government spending which is increasing in percentage against the GNP, where this theory is based on observations in European countries, the US, and Japan in the $19^{\text {th }}$ century (Mangkoesoebroto, 2012: 167). Wagner 
expressed his opinion in the form of a Wagner law, as follows: In an economy, if per capita income rises, government spending will increase in relative terms.

The budget used to carry out government activities, one of which is development spending in various sectors. Development carried out by the government is planned in the formulation of the budget that will be used in the implementation of development, because the budget is a very important variable in community development. The allocation of government funds in the budget (budget) which acts as a means of regulating the order of development priorities by considering the objectives to be achieved. therefore, development efforts must always be based on Pancasila, the 1945 Constitution, and the Development Trilogy. (Suparmoko, 2013:49).

Government spending can be assessed in various ways divided into four classifications as follows, (Suparmoko, 2013:12):

a. Government expenditure is an investment to increase strength and economic resilience in the future.

b. Government expenditure directly provides welfare for the community.

c. Government expenditure is future expenditure.

d. Government expenditure is a means of providing more employment opportunities and wider distribution of purchasing power.

Seeing the development of government activities from year to year, the role of government tends to increase. The increase in government activity is due to several factors because:

1) An increase in the level of community income, then the needs of the community also increase. This has resulted in increased government activities to meet the needs of the community, such as the need for public transportation, education, and health infrastructure.

2) Population development. This requires an increase in government activities to keep pace with the development of the population in meeting the needs of the population.

3) Economic development also requires a large role for the government to fill economic activities.

\section{Government Funds for Education}

Development spending on the development sector can be allocated to provide educational infrastructure and provide educational services to the entire population equally. The education budget of $20 \%$ (percent) is a form of government realization to improve education. Investment in terms of education is necessary, the government must be able to build a means and a good education system. The budget allocation for government expenditure on education is a tangible manifestation of investment to increase community productivity.

Development in education implies that human life will be more quality. Concerning the economy in general (national) the higher the quality of life of a nation, the higher the level of growth and welfare of the nation. The higher the quality of life/investment of high-quality human resources will also have implications for the level of national economic growth. (Setiawan, 2016: 12) 
Continuous learning is indeed necessary, but people can learn from experience without receiving formal teaching. If there is transportation, by itself many farmers will travel to visit cities. As a result, new knowledge and ideas will be obtained. So, people can learn without formal facilities for education. The existence of formal facilities can accelerate the learning process (Hanafie, 2012: 16).

Inadequate education and not being developed continuously will certainly make a nation not ready to compete with other nations. Although difficult to record in statistical documents, expanding opportunities for schooling at all levels has driven economic growth aggressively through (Todaro and Smith, 2012: 47):

a. The creation of a more productive workforce due to better knowledge and skills.

b. Availability of wider employment opportunities.

c. Creation of an educated leadership group to fill vacancies in a business unit or institution.

d. The creation of various education and training programs to foster modern attitudes.

\section{Government Funds for Health}

The level of public health can be seen based on the quality and services provided by the government for public health. Patients/communities see quality health services as a health service that can meet the needs that are felt and organized in a manner that is polite and polite, timely, responsive and able to cure complaints and prevent the development or spread of disease (Pohan, 2016: 13). To realize the level of public health, it is necessary to have a budget that becomes expenditure for a city through tax collection for the community. The choice of tax type becomes very important in efforts to improve tax compliance. Fluctuations in tax compliance will affect the acquisition of tax revenue and subsequently will have an impact on local government spending which will ultimately have an impact on economic growth (Simanjuntak, 2012: 198).

\section{Employment}

Based on Law No. 13 of 2003 Chapter 1 article 1 Paragraph 2 which states that someone who can do a job to produce goods or services to meet their own needs or for the surrounding community. As a whole, the population in a government or state has two groups which are laborers and not laborers. Age determined by the Indonesian government aged 15-64 years. So everyone able or able to work is called labor.

Law 13 of 2003, every person who can do work that produces goods or services, both to meet their own needs and for the community is called labor (Agusmidah, 2012: 6). According to Payaman Simanjuntak, manpower is a resident who is or is currently working, is looking for work, and who is carrying out other activities, such as going to school and managing the household. The definition of labor and not labor according to him is determined by age or age. 
Manpower is basically a population of working age (aged 15-64 years) or the total population in a country that can produce goods and services if there is demand for their labor, and if they want to participate in these activities (Mulyadi, 2012: 59). The labor market is not much different from the existing goods market in the classical view. There will be a balance between labor supply and labor demand, if the price of labor (wages) is flexible enough.

\section{Gross Regional Domestic Product}

An important indicator to be able to know the economic conditions of a region in a certain period is to use Gross Regional Domestic Product (GRDP) data, which can use at current prices or constant prices. According to Sukirno (2016: 24), economic growth is an increase in output per capita, in the long run, the emphasis is on three aspects namely process, output per capita, and long term. Economic growth is a process, not just a brief economic picture. Regional development and sectoral development must be carried out in a line so that sectoral development in the regions can run according to regional potentials and priorities. Gross Regional Domestic Product (GRDP) is the amount of added value generated for all business areas and services in an area applying the amount the entire value of final goods and services produced by all economic units. GRDP itself can be interpreted as the amount of added value generated by all business units or is the total value of goods and services by all economic units in a region.

GRDP is calculated based on current prices and at constant prices. GRDP at current prices (nominal) or At current nominal prices which shows the ability of economic resources in a region to produce output in a period that is valued at current prices. GRDP at current prices is used to see the structure of the economy or the role of each sector and the picture of the economy in the current year. GRDP based on constant prices or constant prices is used to see the economic growth of a region both overall and sectoral.

\section{The Development of GRDP is Based on Several Factors}

Price Changes are increase/decrease in the economy caused by changes in prices that occur in the market. In general, these prices tend to increase so that regional income based on current prices from year to year always shows an increase.

Real Change Is an increase/decrease in the economy calculated based on real changes, meaning that prices are not included anymore. The common understanding used by economists is that income has been eliminated from the influence of inflation.

Regional income based on current prices that have been reduced by inflation is known as regional income at constant prices. This latter regional income is generally widely used by bureaucrats, researchers, and economists. 


\section{Hypothesis}

The hypothesis is a temporary answer to the formulation of the research problem, where the research problem formulation has been stated in the form of sentence questions (Sugiyono, 2012: 25). The hypotheses in this study are:

1. It is suspected that local government spending on education funds has a partial effect on gross regional domestic product.

2. It is suspected that local government spending on health funds partially influences gross regional domestic product.

3. It is suspected that labor absorption partially influences gross regional domestic product.

\section{Framework for Thinking}

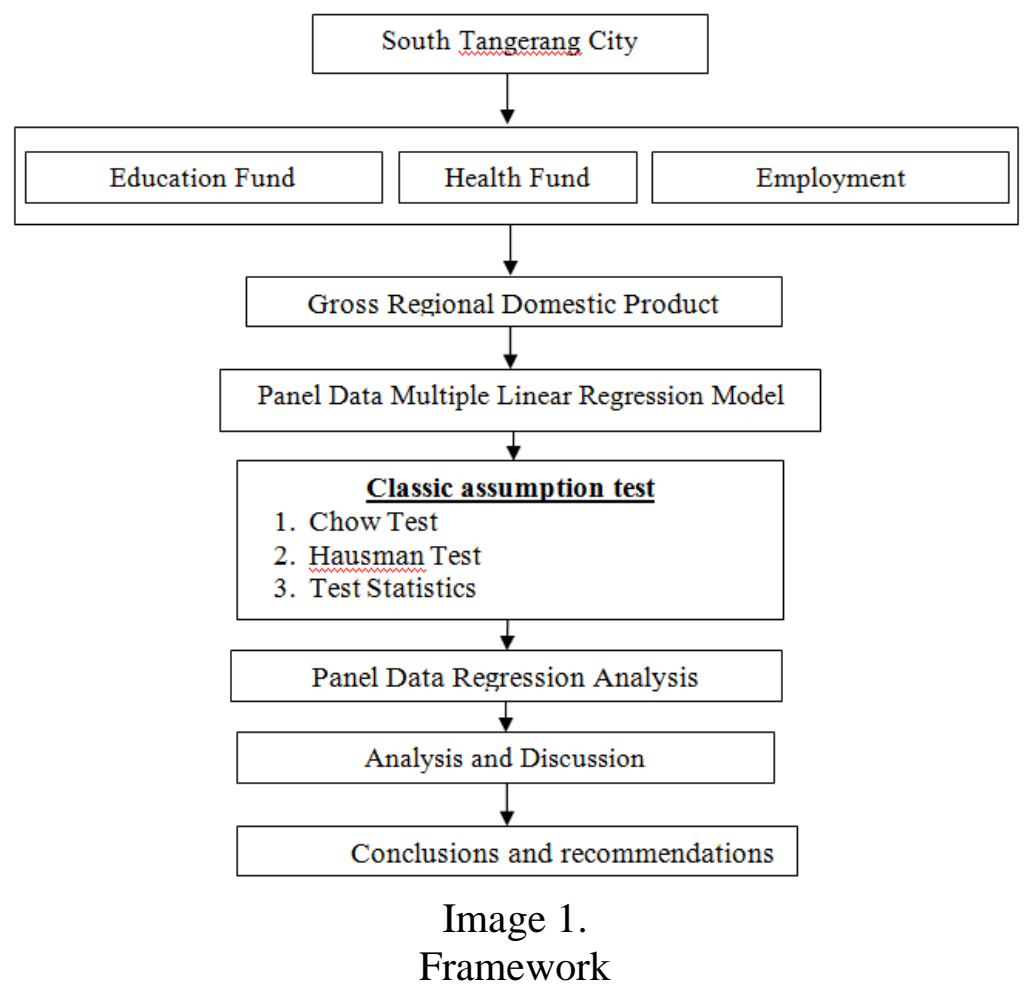

\section{RESEARCH METHODS}

The research conducted is an empirical study in which the researcher is directly involved in the research. This study was conducted to analyze how much influence the government education funds $\left(\mathrm{X}_{1}\right)$, government health funds $\left(\mathrm{X}_{2}\right)$ and employment $\left(\mathrm{X}_{3}\right)$ on the gross regional domestic product $(\mathrm{Y})$.

In this study, samples are not needed. Because the entire research object can be reached by researchers. The population studied is government expenditure on education, health and employment absorption and gross regional domestic product in South Tangerang City in 2013 - 2018. 
The method used in this study uses panel data regression analysis to determine the effect of education funds, health funds and labor absorption on the gross regional domestic product (GRDP). The method used to analyze this research is quantitative data using multiple regression analysis models, with some testing data from BPS Kota Tangerang Selatan. Variables consisting of dependent variables $(\mathrm{Y})$ and independent variables $(\mathrm{X})$. The dependent variable consists of one variable, namely gross regional domestic product (GRDP) and the independent variable consisting of education funds, health funds, and employment. From these variables, an analysis will be examined whether the influence of variable $\mathrm{X}$ on the $\mathrm{Y}$ variable in the regression analysis. The analysis will use analysis tools in the form of a software Eviews 9.0.

The data analysis model used in this study is multiple linear analysis models using EViews 8.1 software. The multiple regression analysis models are used to measure the effect of more than one independent variable on the dependent variable. The test criteria performed are using the coefficient of determination test $\left(\mathrm{R}_{2}\right)$, a statistical test of partial regression coefficients (t-test) and $\mathrm{F}$ statistic testing.

1. Classical Assumption Test

a. Normality test

Data that is normally distributed is one of the assumptions in statistical analysis. This test uses E-Views software and uses two programs, namely histogram and Jarque-Bara Test

b. Multicollinity Test

Multicollinearity means there is a near perfect linear correlation between two independent variables. Multicollinearity test aims to test whether in the regression model that is formed there is a high or perfect correlation between independent variables or not. If in the regression model formed there is a high or perfect correlation between the independent variables, then the regression model is stated to contain multicollinear symptoms. (Suliyanto, 2011: 81)

c. Heteroscedasticity Test

There are several methods used to identify the presence or absence of heteroscedasticity, namely using the graph method, Park Test, Glejser Test, Spearman Correlation Test, Goldfield Quandt Test, BrueschPagan-Godfrey Test and White Test (Winarno, 2009: 5.8).

d. Autocorrelation Test

Autocorrelation is the relationship between one observation residual and another observation residual. Autocorrelation is more likely to arise in time-coherent data, because by their very nature, current data is influenced by previous data. Autocorrelation also often occurs in data that is between objects (cross section). (Winarno, 2009: 26)

2. Coefficient of Determination $\left(\mathrm{R}^{2}\right)$

3. Significance Test 


\section{RESULTS AND DISCUSSION}

\section{Hypothesis test}

\section{a. Statistic test}

The following are the results of the fixed effect estimation model using the GLS approach.

Table 1.

\section{Results of Calculation of Panel Data Estimation for The GLS Method}

Dependent Variable: PDRB?

Method: Pooled Least Squares

Date: 09/26/19 Time: 13:45

Sample: 20132018

Included observations: 6

Cross-sections included: 7

Total pool (balanced) observations: 42

\begin{tabular}{|c|c|c|c|c|}
\hline Variable & Coefficient & Std. Error & t-Statistic & Prob. \\
\hline $\mathrm{C}$ & $2.01 \mathrm{E}+12$ & $6.16 \mathrm{E}+11$ & 3.260966 & 0.0026 \\
\hline DP? & -18.80265 & 1496.453 & -0.012565 & 0.9901 \\
\hline DK? & 3423.041 & 1113.390 & 3.074431 & 0.0043 \\
\hline PTK? & -18231694 & 29692377 & -0.614019 & 0.5435 \\
\hline \multicolumn{5}{|l|}{ Fixed Effects (Cross) } \\
\hline _CIPUTAT--C & $1.72 \mathrm{E}+12$ & & & \\
\hline _CIPUTAT_TIMUR--C & $-1.78 \mathrm{E}+10$ & & & \\
\hline _PAMULANG--C & $-1.03 \mathrm{E}+12$ & & & \\
\hline _PONDOK_AREN--C & $-5.33 E+11$ & & & \\
\hline SSERPONG--C & $-8.06 \mathrm{E}+11$ & & & \\
\hline _SERPONG_UTARA--C & $-5.72 \mathrm{E}+09$ & & & \\
\hline _SETU--C & $6.65 \mathrm{E}+11$ & & & \\
\hline \multicolumn{5}{|c|}{ Effects Specification } \\
\hline \multicolumn{5}{|c|}{ Cross-section fixed (dummy variables) } \\
\hline R-squared & 0.475389 & \multicolumn{2}{|c|}{ Mean dependent var } & $2.89 \mathrm{E}+12$ \\
\hline Adjusted R-squared & 0.327842 & \multicolumn{2}{|c|}{ S.D. dependent var } & $1.45 \mathrm{E}+12$ \\
\hline S.E. of regression & $1.19 \mathrm{E}+12$ & \multicolumn{2}{|c|}{ Akaike info criterion } & 58.64671 \\
\hline Sum squared resid & $4.51 \mathrm{E}+25$ & \multicolumn{2}{|c|}{ Schwarz criterion } & 59.06044 \\
\hline Log-likelihood & -1221.581 & \multicolumn{2}{|c|}{ Hannan-Quinn criteria. } & 58.79836 \\
\hline F-statistic & 3.221948 & \multicolumn{2}{|c|}{ Durbin-Watson stat } & 2.305719 \\
\hline Prob(F-statistic) & 0.006852 & & & \\
\hline
\end{tabular}

Source: Data processed, 2019

1) R-squared coefficient results (Determination coefficient)

Following the estimation model table above, the R-squared (R2) value obtained from the FEM estimation model of the GLS approach is $47 \%$, which means, the variable education funds, health funds, and 
employees can explain the variable gross regional domestic product (GRDP) of $47 \%$. It can be said that the $47 \%$ gross regional domestic product (PDRB) is influenced by education funds, health funds, and employment, the remaining $53 \%$ can be explained/influenced by other variables beyond the three variables.

2) F-statistic test (Simultaneous Significance / Model)

How to test F-statistics are as follows:

$\mathrm{H}_{0}$ : The influence of variable $\mathrm{x}$ together on the variable $\mathrm{y}$

$\mathrm{H}_{1}$ : There is no influence between variables $\mathrm{x}$ together on the $\mathrm{y}$ variable

In this study, the alpha value or significance was $5 \%(0.05)$, while the F-statistic probability value was 0.006852 . It can be said that the F-statistic probability value is smaller than the alpha value, so it can be concluded that the model the researcher is using is good (it can simultaneously affect the variable y).

Education funds, health funds, and workforce absorption together have a positive and significant effect on gross regional domestic product in 2013 - 2018 The result is that the F-statistical probability value is smaller than 0.05 , so the initial hypothesis of the researcher is accepted.

3) Test t-statistics (Probability t-statistics)

Following the GLS estimation model table, the variable education fund has a probability value of 0.9901 , the effect produced by this variable is negative, as seen from the coefficient value of 18.80265 which can be interpreted, if the education fund increases by 1 percent will cause the value Gross regional domestic product fell also by 18.8265 percent.

While for the health fund variable, it has an at-statistic probability value of 0.0043 . The relationship that occurs is positive, because the coefficient of the variable health fund is 3423,041 , which can be interpreted, if the health fund rises by one percent, it will cause an increase in the value of the gross regional domestic product of 3423,041 percent (assuming others are the same / ceteris paribus).

The last variable is the employment variable. The t-statistic probability value for this variable is 0.5435 , the relationship is negative because the coefficient of this variable is -18231694 . Where when there is an increase in labor absorption of one percent, it will cause the value of the gross regional domestic product to fall by 1823,1694 percent but not significantly. 


\section{Model Analysis}

\section{a. Technical Analysis}

The following are the results of the panel data regression model analysis:

Table 2.

\section{Results of GLS Method Panel Data Interpretation}

Dependent Variable: PDRB?

Method: Pooled Least Squares

Date: 09/26/19 Time: 13:45

Sample: 20132018

Included observations: 6

Cross-sections included: 7

Total pool (balanced) observations: 42

\begin{tabular}{|c|c|c|c|c|}
\hline Variable & Coefficient & Std. Error & t-Statistic & Prob. \\
\hline $\mathrm{C}$ & $2.01 E+12$ & $6.16 \mathrm{E}+11$ & 3.260966 & 0.0026 \\
\hline DP? & -18.80265 & 1496.453 & -0.012565 & 0.9901 \\
\hline DK? & 3423.041 & 1113.390 & 3.074431 & 0.0043 \\
\hline PTK? & -18231694 & 29692377 & -0.614019 & 0.5435 \\
\hline \multicolumn{5}{|l|}{ Fixed Effects (Cross) } \\
\hline _CIPUTAT--C & $1.72 \mathrm{E}+12$ & & & $3.73 \mathrm{E}+12$ \\
\hline _CIPUTAT_TIMUR--C & $-1.78 \mathrm{E}+10$ & & & $1.99 \mathrm{E}+12$ \\
\hline _PAMULANG--C & $-1.03 E+12$ & & & $9.80 \mathrm{E}+11$ \\
\hline _PONDOK_AREN--C & $-5.33 E+11$ & & & $1.48 \mathrm{E}+12$ \\
\hline _SERPONG--C & $-8.06 \mathrm{E}+11$ & & & $1.20 \mathrm{E}+12$ \\
\hline _SERPONG_UTARA--C & $-5.72 \mathrm{E}+09$ & & & $2.00 \mathrm{E}+12$ \\
\hline _SETU--C & $6.65 \mathrm{E}+11$ & & & $2.68 \mathrm{E}+12$ \\
\hline \multicolumn{5}{|c|}{ Effects Specification } \\
\hline \multicolumn{5}{|c|}{ Cross-section fixed (dummy variables) } \\
\hline R-squared & 0.475389 & \multicolumn{2}{|c|}{ Mean dependent var } & $2.89 \mathrm{E}+12$ \\
\hline Adjusted R-squared & 0.327842 & \multicolumn{2}{|c|}{ S.D. dependent var } & $1.45 \mathrm{E}+12$ \\
\hline S.E. of regression & $1.19 \mathrm{E}+12$ & \multicolumn{2}{|c|}{ Akaike info criterion } & 58.64671 \\
\hline Sum squared resid & $4.51 \mathrm{E}+25$ & \multicolumn{2}{|c|}{ Schwarz criterion } & 59.06044 \\
\hline Log-likelihood & -1221.581 & \multicolumn{2}{|c|}{ Hannan-Quinn criteria. } & 58.79836 \\
\hline F-statistic & 3.221948 & \multicolumn{2}{|c|}{ Durbin-Watson stat } & 2.305719 \\
\hline Prob(F-statistic) & 0.006852 & & & \\
\hline
\end{tabular}

Source: Data processed, 2019

General functions (South Tangerang):

PDRB $=2,01 \mathrm{E}+12-18,80265 *$ LOGPEND $+3423,041 *$ LOGKES $-18231694 *$ LOGPTK

1) When education funds increase by $1 \%$, the value of GRDP will decrease by $18.80265 \%$.

2) When the health fund increases by $1 \%$, the GRDP value will increase by $3423,041 \%$. 
3) When the absorption of labor rises by $1 \%$, the value of the GRDP will decrease by $18231694 \%$.

4) When there is no increase or decrease in education funds, health funds, and employment, the GRDP value will increase by $2.01 \mathrm{E}+12$ units.

\section{Economic Analysis}

\section{Education Fund}

According to the results of technical analysis, education funding has a negative and insignificant relationship, which means that each increase of one percent in the education sector will cause the gross regional domestic product to also be reduced by 18,80265 percent except for other conditions ceteris paribus (other conditions are fixed). When education funds go down by $1 \%$, it will cause GRDP in South Tangerang City to increase by $2.01 \mathrm{E}+12$ index units ([0.01* $18.80265]+2.01 \mathrm{E}+12$ )

The negative relationship occurs due to education funds in the form of school operational assistance, assistance funds for underprivileged children, teacher allowance assistance can increase insight and knowledge and can make an individual longer to attend school (9-year compulsory education), where knowledge insight and length of schooling is one of the second dimensions of decent living GRDP However, the increase occurred only by $2.01 \mathrm{E}+12$ units if the education fund rose by $1 \%$, where the average government education sector expenditure ranged from 10-60 Trillion from 2013-2018. Seeing this condition, it would be better if government spending in the education sector was increased and more closely monitored the policies of the education sector expenditure, for example, education guarantee assistance, more monitored the use process so that all individuals can fund all individuals to live properly according to the dimensions first GRDP. So that later when there is only a $1 \%$ increase in education sector spending can further increase the value of GRDP in South Tangerang City

\section{Health Funds}

Following the results of technical analysis, health funds have a positive and significant relationship, which means that every one percent increase in the health sector will cause the gross regional domestic product to increase by 3423,041 percent except for other conditions ceteris paribus (the other conditions are fixed). When the health fund increases by $1 \%$, it will cause the GRDP in South Tangerang City to increase by $2.01 \mathrm{E}+12$ index units $([0.01 *+3423.041]+$ 2.01E + 12).

This positive relationship occurs because government spending in the health sector in the form of health insurance assistance, health insurance for pregnant and lactating women can make an individual live healthier and live longer according to the first decent living dimensions of the GRDP so that the quality of human resources represented by the GRDP value will increase. However, the increase occurred only by $2.01 \mathrm{E}+12$ index units if the health fund increased by $1 \%$, where 
the average government health sector spending ranged from 10 to 60 trillion from 2013 - 2018. Seeing this condition, it would be even better if health funds are improved and more closely monitored the running of policies from health funds, for example, health insurance assistance, more closely monitored the use process so that all individuals can access JKN more easily and all individuals can live properly according to the first dimension of the GRDP. So that later when there is only a $1 \%$ increase in health sector spending can further increase the value of GRDP in South Tangerang City.

\section{Labor Absorption}

According to the results of technical analysis, employment absorption has a negative and insignificant relationship, which means that every one percent increase in the labor sector will cause gross regional domestic product to also be reduced by 1823,1694 percent with the exception of other conditions ceteris paribus (other conditions are fixed). When Manpower Absorption funds decrease by $1 \%$, it will cause GRDP in South Tangerang City to increase by $2.01 \mathrm{E}+12$ index units $([0.01 *-18231694]+2.01 \mathrm{E}+12)$.

The negative relationship occurred due to labor absorption in the form of unemployment reduction, employment opportunities, where work is one of the second dimensions of decent living GRDP However, the increase occurred only by $2.01 \mathrm{E}+12$ units when labor absorption increased by $1 \%$, where the average government expenditure in the labor sector ranges from 9-40 Trillion from 20132018. Seeing this condition, it would be better if government spending in the employment sector is increased and more closely monitored the running of policies from the labor sector expenditure, for example, the provision of labor, increasing the number of employers who can absorb labor, more closely monitored the use process so all individuals can fund all individuals can live according to the first dimension of GRDP. So that later when there is only a $1 \%$ increase in labor sector expenditure can further increase the value of GRDP in South Tangerang City

\section{E. CONCLUSION}

Based on the results of research and discussion on the influence of education funds, health funds and employment in the regional gross domestic product, the following conclusions can be drawn:

1. Based on the partial panel data regression results, the results of the t-test show that the education funding variable does not affect the gross regional domestic product (GRDP).

2. Based on the results of partial panel data regression, the results of the t-test show that the health fund variable influences gross regional domestic product (GRDP).

3. Based on the results of partial panel data regression, the results of the t-test show that the employment absorption variable does not affect gross regional domestic product (GRDP). 
4. Based on the results of simultaneous panel data regression, the results of the $F$ test show that the three independent variables, namely education funds, health funds, and workforce absorption simultaneously affect the gross regional domestic product (GRDP).

\section{REFERENCES}

Abdullah Syukriy dan Abdul Halim. "Study of Capital Expenditures in Local Government Budgets concerning Government Expenditures and Revenue Sources”. Journal of Government Accounting vol. 2, No. 2, 2016.

Agusmidah. "The Dynamics of Indonesian Labor Law. Medan USU Press. Medan, 2012.

Case, E. Karl dan Fair, "Economic principles. Jakarta, Erlangga, 2015.

Hanafie, Mahmud M. "Financial management". Fifth print. Yogyakarta: BPFE, 2012.

Mangkoesoebroto, Guritno. "Public Economy", Third Edition, BPFE, Yogyakarta, 2012.

Mankiw N, Gregory, dkk. "Introduction to Macro Economics". Jakarta: Salemba Empat, 2012.

Mulyadi. "Cost accounting". STIE YKPN. Jakarta. 2012.

Pohan. Quality Assurance of Health Services: Basics of Understanding and Application ". Jakarta: EGC Medical Book. 2016

Samuelson and Nordhaus. "Macroeconomics". Jakarta: PT Media Global. 2012.

Setiawan, Achmad Hendra. "Analysis of Manpower Absorption in the Sector of Small and Medium Enterprises (SMEs) in the City of Semarang". Research Journal - Vol.3, No.1, 2010. Pg. 39-47. 2016

Suparmoko, M and Irawan. "Economic development". Sixth edition. Yogyakarta: BPFE, 2013.

Simanjuntak, Timbul Hamonangan and Imam Mukhlis. "The Economic Dimension of Taxation in Economic Development". Bogor: Publisher Raih Asa Sukses, 2012.

Sudjana. "Statistical Method". Jakarta: Rineka Cipta. 2017.

Sugiyono "Qualitative Quantitative Research Methods and R\&D". Bandung: Alfabeta. 2012.

Sukirno. "Macroeconomics. Introduction Theory ". Third Edition. PT. Raja Grasindo Persada. Jakarta, 2016. 
Suliyanto. Applied Econometrics: Theory and Application with SPSS. Yogyakarta: ANDI, 2011

Todaro, M. P. "Economic Development". Jakarta. Erlangga 2012

Widarjono. "Introduction to Econometrics and Their Applications". Ekonosia. 2013

Winarno, Wing Wahyu. "Analysis of econometrics and statistics with eviews". Second edition. YKPN STIM UPP. Yogyakarta. 2009

www.bps.go.id

www.djpk.depkeu.go.id 